
DOI:10.1017/RDC.2018.96

\title{
AGE ESTIMATES ON THE DEPOSITION OF THE CAVE ICE BLOCK IN THE SAARHALLE DACHSTEIN-MAMMOTH CAVE (MAMMUTHÖHLE, AUSTRIA) BASED ON ${ }^{3} \mathrm{H}$ AND ${ }^{14} \mathrm{C}$
}

Kern $Z^{1,2 *}$, Palcsu L ${ }^{2}$, Pavuza $\mathrm{R}^{3}$, Molnár $\mathrm{M}^{2}$

1. Institute for Geological and Geochemical Research, Research Centre for Astronomy and Earth Sciences, MTA, Budaörsi út 45., Budapest, H-1112, Hungary

2. Isotope Climatology and Environmental Research Centre (ICER), MTA ATOMKI, Bem tér 18/c, Debrecen, Hungary

3. Working Group of Karst and Cave Science at the Natural History Museum Vienna, Burgring 7, Vienna, Austria

Correspondence to: Zoltán Kern; E-mail: kern.zoltan@csfk.mta.hu

\begin{abstract}
Measurements of the radiocarbon and tritium activity in a $5.8 \mathrm{~m}$ long ice core from the Saarhalle, Dachstein-Mammoth Cave allowed a substantial revision of previous opinions concerning the age of the ice block, and provide useful experience that may be applied to future ${ }^{14} \mathrm{C}$ dating of cave ice deposits. The stepped combustion technique results in a remarkably older radiocarbon age for the $800^{\circ} \mathrm{C}$ than for the $400^{\circ} \mathrm{C}$ fractions of the carbonaceous matter from ice layer samples. The highest tritium activity (37.2 $\pm 1.2 \mathrm{TU})$ can be linked to the period of anthropogenically increased tritium activity of atmospheric precipitation at the mid-1960s, providing a well-dated radiochemical reference horizon. Compared the ${ }^{3} \mathrm{H}$-based extrapolated ages of two shallow samples to the expected atmospheric signal an average ${ }^{14} \mathrm{C}$ reservoir bias of $\sim 1500 \mathrm{BP}$ was obtained for the insoluble organic fraction combusted at $400^{\circ} \mathrm{C}$. The conventional ${ }^{14} \mathrm{C}$ age measured for the $400^{\circ} \mathrm{C}$ fraction of the deeper samples has been corrected with the average reservoir bias. The median calibrated age of the deepest analyzed sample of the ice profile is $\sim 1830 \mathrm{cal}$ BC and a linear extrapolation to the bottom ice layer gave 2590 cal BC making Saarhalle ice block among the oldest dated cave ice deposits known in the Alpine domain.
\end{abstract}

Keywords: cave ice, tritium, ice core, stepped combustion, insoluble organic material, Holocene, Alps

\section{INTRODUCTION}

One of the most important issues when considering sub-surface ice deposits and their potential use as paleoclimate archives is their age (Luetscher et al. 2013). There might be plenty of options for dating near-surface cave ice deposits (Luetscher et al. 2007; Kern 2018). Radiocarbon $\left({ }^{14} \mathrm{C}\right)$ analysis has became the most frequently-used option, allowing the direct dating of cave ice sequences, at least when sufficient organic remnants are to be found (e.g., Hercmann et al. 2010; Perşoiu and Pazdur 2011; Sancho et al. 2012, 2018; Spötl et al. 2014; Gradziński et al. 2016; Munroe et al. 2018; Perşoiu et al. 2017). However, the dating of cave ice bodies settled deep in the high mountain karstic environment is often a great challenge due to the relative scarcity of embedded organic materials (e.g. May et al. 2011).

A novel dating approach was introduced a decade ago, targeting glacier ice cores, and based on extracting at the microgram level organic carbon fractions embedded in the ice matrix for ${ }^{14} \mathrm{C}$ dating (Jenk et al. 2006, 2007). The approach was first tested on samples derived from 
Preprint of Kern Z., Molnár, M., Palcsu, L. Pavuza R. (2018) Age estimates on the deposition of the cave ice block in the Saarhalle Dachstein-Mammoth Cave (Mammuthöhle, Austria) based on ${ }^{3} \mathrm{H}$ and ${ }^{14} \mathrm{C}$. RAdiocarbon 60: 1379-1389. DOI:10.1017/RDC.2018.96

cave ice core from Eisriesenwelt (May et al. 2011). Although radiocarbon dating performed on small particulate organic matter separated from the cave ice samples proved inconclusive, probably due to a background contamination introduced by the antifreeze drilling liquid applied, a crude estimate giving a basal ice age in the order of several thousand years could be achieved. The method for surface ice cores has since been further improved (Uglietti et al. 2016; Hoffmann et al. 2017) and cave ice also re-considered as potential targets in the Alpine cryosphere (Hoffmann et al. 2015; Colucci et al. 2018).

The age of meteoric waters originating from modern (i.e. post mid- $20^{\text {th }}$ century) precipitation can be estimated based on their tritium $\left({ }^{3} \mathrm{H}\right)$ activity. Tritium is a valuable tool in the determination of the age of a cave ice deposits formed from meteoric waters over the past 6070 years (Borsato et al. 2006; Kern et al. 2009).

In the research presented here, the ${ }^{14} \mathrm{C}$ analysis of carbonaceous particulate matter was tested on archived ice samples available from a cave ice core extracted without the use of antifreeze drilling liquid. The samples were taken from the Saarhalle ice block in the DachsteinMammoth cave (Mammuthöhle), Austria. Tritium activity has already been measured in eight water samples from the melted ice core of the Saarhalle Dachstein-Mammoth Cave using the liquid scintillation counting (LSC) technique (Kern et al. 2011). None of those samples, however, provided detectable tritium activity. In this study a more sensitive method was applied to measure the ${ }^{3} \mathrm{H}$ activity of additional samples from the upper part of the ice core. The new radiometric ages allowed the placing of chronological constraints on the $5.8 \mathrm{~m}$ long profile and supported a substantial revision of previous opinion concerning the age of the ice block.

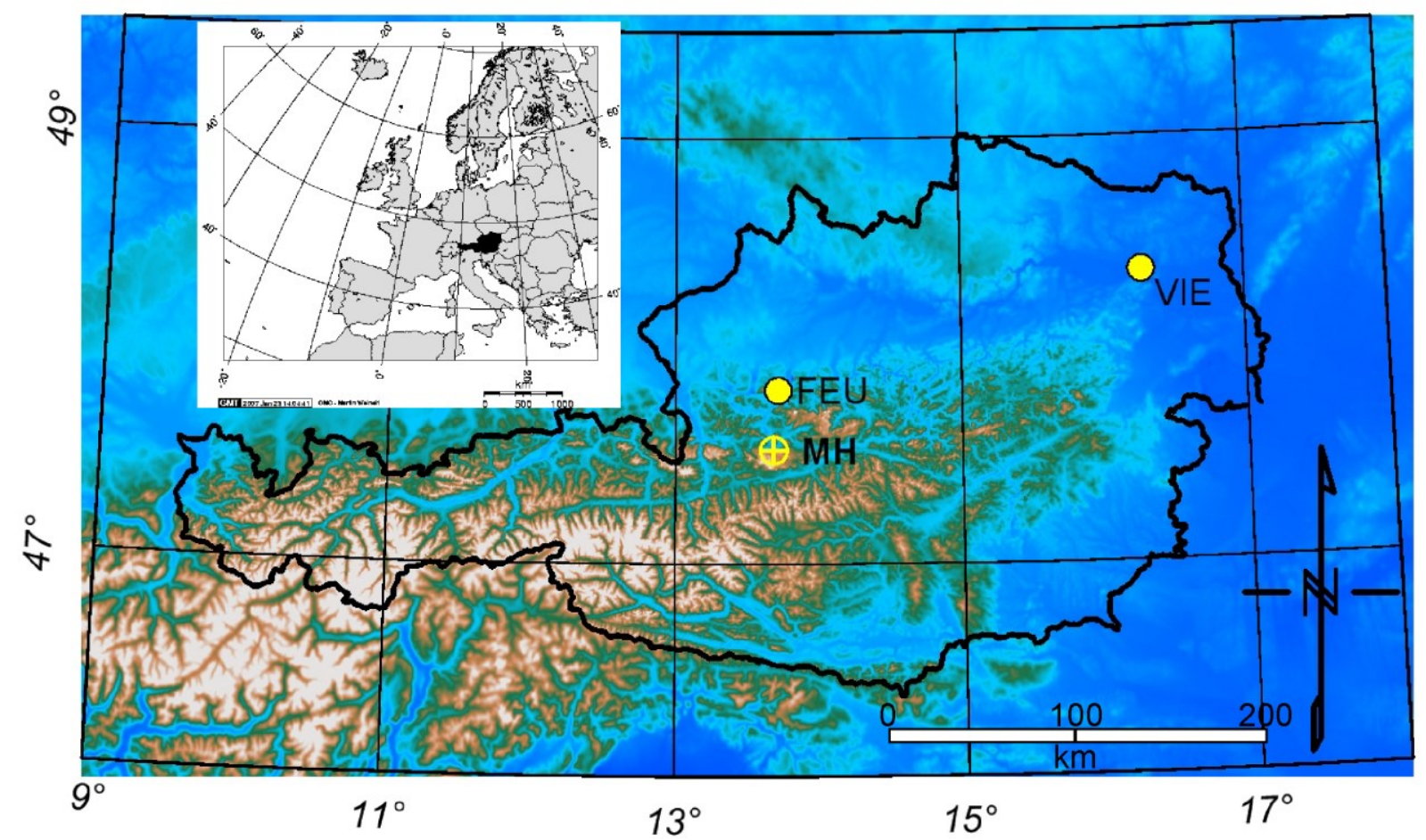

Figure 1 Relief map of Austria with the location of Dachstein-Mammoth Cave (MH) and the reference stations (Feuerkogel: FEU and Vienna: VIE). The inset map shows the location of Austria within Europe in black. 
Preprint of Kern Z., Molnár, M., Palcsu, L. Pavuza R. (2018) Age estimates on the deposition of the cave ice block in the Saarhalle Dachstein-Mammoth Cave (Mammuthöhle, Austria) based on ${ }^{3} \mathrm{H}$ and ${ }^{14} \mathrm{C}$. Radiocarbon 60: 1379-1389. DOI:10.1017/RDC.2018.96

\section{SITE DESCRIPTION}

The cave system is located in the Dachstein Mts of the Northern Calcareous Alps (Fig. 1). The total length of all passages in Dachstein-Mammoth Cave amounts to $67.5 \mathrm{~km}$, and the vertical extension is $1.2 \mathrm{~km}$ making it the fourth longest and fifth deepest cave in Austria (Spötl et al. 2016). Perennial ice is present in two huge chambers, Feenpalast and Saarhalle, not far from the western entrance (Spötl et al., 2018). These glaciated chambers have been targets of annual ice level measurements in combination with cave air monitoring since the 1990s (Mais and Pavuza, 2000). The monitoring data revealed that the air temperature in the Saarhalle follows the temperature fluctuations of the Feenpalast with a reduced amplitude during the winter ventilation regime ( from November to early May, Mais and Pavuza, 2000) suggesting that the cold outside air flows in the Saarhalle chamber via the Feenpalast. While, air temperature rises slightly above the freezing point $\left(0.1-0.2^{\circ} \mathrm{C}\right)$ during the rest of the year. The mean annual air temperature in the Saarhalle ranged from $-0.46^{\circ} \mathrm{C}$ to $-0.10^{\circ} \mathrm{C}$ in the period 1996-2000, and the long-term average was $-0.30^{\circ} \mathrm{C}$ (Mais and Pavuza 2000). Dripping water entering to the Saarhalle chamber passes through a $\sim 60 \mathrm{~m}$ thick rock overburden. This type of water supply has probably fed the ice accumulation in historical times. However, no current ice accumulation was observed in this chamber; rather, the ice level shows a steady decline since 1996 at a nearly constant rate of $-7 \mathrm{~cm} / \mathrm{yr}$ (Mais and Pavuza 2000, unpublished data until 2014).

The lateral extension of the Saarhalle ice body is $40 \mathrm{~m} \times 15 \mathrm{~m}$ (Behm and Hausmann 2008) and the estimated maximum ice thickness, determined by ground penetrating radar, was $\sim 6 \mathrm{~m}$ in 2008 (Hausmann and Behm 2011).

\section{METHODS}

\section{Ice drilling and sample selection}

A $5.28 \mathrm{~m}$ long ice core was extracted from the Saarhalle ice block in September 2009 and sectioned into 105 sub-samples on the spot, each subsample's length being $\sim 5 \mathrm{~cm}$ (Kern et al. 2011). The melted samples not used in the first stage of the analysis were stored in wellsealed centrifuge tubes at room temperature. Five samples were selected from the stored ice core samples in 2015 to test the AMS radiocarbon analysis of the water-insoluble carbonaceous matter embedded in the ice, and 11 samples were selected from the upper $2 \mathrm{~m}$ section in 2012 for ${ }^{3} \mathrm{He}$-ingrowth analysis using noble gas mass spectrometry.

\section{Radiocarbon analysis by stepped combustion}

A standard pre-treatment with 1-2 mL C-free hydrochloric-acid (1N) was added to the melted samples (1-2 mL liquid) and reacted at $75^{\circ} \mathrm{C}$ for 2 hours in order to remove inorganic carbon (Molnár et al. 2013a). Pre-treated samples were then freeze-dried into quartz combustion tubes and subjected to stepped combustion in pure $\mathrm{O}_{2}$ gas atmosphere first at $400^{\circ} \mathrm{C}$ (Step 1), then at $800^{\circ} \mathrm{C}$ (Step 2) (Ujvári et al. 2016). In Step $1\left(400^{\circ} \mathrm{C}\right.$ combustion) the easy-burning non-charred organic carbon is released from the ice samples, while afterwards in Step2 all the rest of the charred carbon fraction is mobilized, including elemental sources. The developed $\mathrm{CO}_{2}$ of the two fractions were graphitized by a sealed-tube graphitization method (Rinyu et al, 2015); and measured separately by the EnvironMICADAS AMS system in Debrecen (Molnár et al. 2013b).

The conventional radiocarbon ages were calculated according to the method to be found in Stuiver and Polach (1977), using the Libby half-life (5568 years), and corrected for isotope fractionation using the AMS measured ${ }^{13} \mathrm{C} /{ }^{12} \mathrm{C}$ ratio, which accounts for both natural and machine fractionation. The calibration of conventional ${ }^{14} \mathrm{C}$ dates to calendar years were 
Preprint of Kern Z., Molnár, M., Palcsu, L. Pavuza R. (2018) Age estimates on the deposition of the cave ice block in the Saarhalle Dachstein-Mammoth Cave (Mammuthöhle, Austria) based on ${ }^{3} \mathrm{H}$ and ${ }^{14} \mathrm{C}$. Radiocarbon 60: 1379-1389. DOI:10.1017/RDC.2018.96

performed using the OxCal 4.2.4 (Bronk Ramsey 2009) program in conjunction with the Northern Hemisphere IntCal13 (Reimer et al. 2013) dataset.

\section{Tritium activity determined by the ${ }^{3} \mathrm{He}$-ingrowth method}

The water samples were first distilled and filled into metal canisters. After degassing, the metal container was closed and stored for several months to allow ${ }^{3} \mathrm{He}$ ingrowth from tritium decay. Finally, the sample containers were connected to the inlet line of the noble gas mass spectrometer and the He fraction was allowed to enter a dual collector noble gas mass spectrometer (VG 5400), and ${ }^{3} \mathrm{He}$ and ${ }^{4} \mathrm{He}$ were measured simultaneously, applying the peak height method. During the sample intake, an ultrapure ${ }^{4} \mathrm{He}$ spike was added to each sample (Palcsu et al. 2010). Tritium activity is expressed in tritium units, (1 TU= $0.119 \mathrm{~Bq} / \mathrm{L}=6.68^{\times} 10^{7}{ }^{3} \mathrm{H}$ atoms $/ \mathrm{L}$ ). The overall precision of the tritium measurements was better than $2.4 \%$ above $1 \mathrm{TU}$, if sample size was larger than $500 \mathrm{~mL}$. For samples of 30 $40 \mathrm{~mL}$, the detection limit is about $0.8 \mathrm{TU}$, roughly one tenth that of the previously applied LSC method.

The ice core derived tritium activity record was then compared to the regionally available historical inventories. The monthly mean tritium concentration of past precipitation was obtained for Feuerkogel from the Austrian Network of Isotopes in Precipitation (Kralik et al. 2003), and for Vienna from the Global Network of Isotopes in Precipitation (IAEA, 2010). The decay-corrected tritium activity both of past precipitation and ice core samples were calculated for 01.09.2009 using a half-life of 12.32 years (Lucas and Unterweger 2000).

\section{RESULTS AND DISCUSSION}

Most of the samples yielded sufficient carbon ( $>0.1 \mathrm{mg}$, Uglietti et al. 2016) for the applied sealed-tube graphitization method and $\mathrm{AMS}{ }^{14} \mathrm{C}$ analysis. The exceptions were the Step 2 fraction of MH24 and both fractions of the $\mathrm{MH} 26$ sample. The obtained conventional ${ }^{14} \mathrm{C}$ results for the Step 2 fraction gave significantly older ages than those of the Step 1 fraction (Table 1). These results send an immediate methodological warning message, because the applied slight acidification and single step combustion at $800^{\circ} \mathrm{C}$ combustion of the total carbon content is a standard protocol in many AMS Labs. However, in the case of single step combustion one would get a 'mixed' result from the different carbon-pools which can then in turn result in a false age estimate.

In addition, the ages obtained for the $800^{\circ} \mathrm{C}$ fractions from stepped combustion stand in contradiction to the stratigraphic position of the samples, while the $400^{\circ} \mathrm{C}$ fractions conform to stratigraphy (Table 1 ). The $400^{\circ} \mathrm{C}$ results can provide only maximum age estimates (the ice layer cannot be older than this age) because the water frozen in the ice layer might have already been carrying aged organic carbon (e.g. derived from the aged soil carbon at the surface during infiltration). These findings provide a plausible explanation for the older-thanexpected age obtained in single step ${ }^{14} \mathrm{C}$ analysis as reported from a cave ice deposit in the Southern Alps (Colucci et al. 2016). 
Preprint of Kern Z., Molnár, M., Palcsu, L. Pavuza R. (2018) Age estimates on the deposition of the cave ice block in the Saarhalle Dachstein-Mammoth Cave (Mammuthöhle, Austria) based on ${ }^{3} \mathrm{H}$ and ${ }^{14}$ C. RADIOCARBon 60: 1379-1389. D0I:10.1017/RDC.2018.96

Table 1 Radiocarbonage results of particulate organic matter separated from the Saarhalle cave ice core.

\begin{tabular}{|c|c|c|c|c|c|c|c|}
\hline sample code & $\operatorname{depth}(m)^{\mathrm{a}}$ & Step $^{b}$ & $\begin{array}{l}\text { C yield } \\
(\mu \mathrm{g})\end{array}$ & Lab code & ${ }^{14} \mathrm{C}$ age $(\mathrm{BP})( \pm 1 \sigma)$ & $\begin{array}{l}{ }^{14} \mathrm{C} \text { bias corr. } \\
(\mathrm{BP})\end{array}$ & $\begin{array}{l}\text { calibrated median date } \\
(95.4 \%)\end{array}$ \\
\hline \multirow{2}{*}{ MH21 } & \multirow{2}{*}{1.11} & 1 & 110 & DeA-9913 & $1180 \pm 35$ & used for $\Delta \mathrm{R}$ & \\
\hline & & 2 & 500 & DeA-8567 & $4975 \pm 40$ & & \\
\hline \multirow{2}{*}{$\mathrm{MH} 24$} & \multirow{2}{*}{1.26} & 1 & 110 & DeA-9914 & $1790 \pm 35$ & used for $\Delta \mathrm{R}$ & \\
\hline & & 2 & 30 & - & & & \\
\hline \multirow{2}{*}{ MH26 } & \multirow{2}{*}{1.36} & 1 & 60 & - & & & \\
\hline & & 2 & 10 & - & & & \\
\hline \multirow[t]{2}{*}{ MH92 } & \multirow[t]{2}{*}{4.62} & 1 & 470 & DeA-6808 & $4550 \pm 40$ & $3030 \pm 80^{c}$ & $\begin{array}{l}1270 \text { cal BC } \\
(1450-1031 \text { cal BC })\end{array}$ \\
\hline & & 2 & 1720 & DeA-6809 & $17140 \pm 80$ & & \\
\hline \multirow[t]{2}{*}{ MH98 } & \multirow[t]{2}{*}{4.90} & 1 & 180 & DeA-6810 & $4990 \pm 70$ & $3500 \pm 100^{c}$ & $\begin{array}{l}1830 \mathrm{cal} \mathrm{BC} \\
(2134-2081(2.9 \%) \\
2060-1608(91.7 \%) \\
1581-1562(0.8 \%))\end{array}$ \\
\hline & & 2 & 160 & DeA-6811 & $10460 \pm 160$ & & \\
\hline
\end{tabular}

a: depth of the midpoint of the represented interval below the September 2009 ice surface

b: fractions of the two-step combustion Step 1: $400^{\circ} \mathrm{C}$ and Step 2: $800^{\circ} \mathrm{C}$

c: propagated error estimated from the analytical uncertainty and the assigned uncertainty of the reservoir bias 
Table 2 Tritium activity with the uncertainty obtained using the ${ }^{3} \mathrm{He}$-ingrowth method of eleven selected samples of the Saarhalle cave ice core.

\begin{tabular}{lll}
\hline sample code & depth $(\mathrm{m})^{\text {a }}$ & \multicolumn{1}{c}{ TU $( \pm 1 \sigma)$} \\
\hline MH03 & 0.14 & $10.18 \pm 0.64$ \\
\hline MH05 & 0.25 & $-0.02 \pm 0.53$ \\
\hline MH09 & 0.48 & $10.05 \pm 0.73$ \\
\hline MH12 & 0.66 & $-0.5 \pm 0.6$ \\
\hline MH15 & 0.81 & $37.24 \pm 1.29$ \\
\hline MH17 & 0.91 & $-0.71 \pm 0.68$ \\
\hline MH20 & 1.06 & $0.04 \pm 0.66$ \\
\hline MH23 & 1.21 & $1.28 \pm 0.8$ \\
\hline MH25 & 1.31 & $0.83 \pm 0.71$ \\
\hline MH27 & 1.41 & $0.3 \pm 0.52$ \\
\hline MH29 & 1.51 & $0.27 \pm 0.63$
\end{tabular}

a: depth of the midpoint of the represented interval below the September 2009 ice surface

A potential explanation for the much lower activity of the Step 2 fraction could be that carbon bearing mineral species lacking detectable ${ }^{14} \mathrm{C}$ and partially resistant to the applied slight acidification remained in the sample and combusted at $800^{\circ} \mathrm{C}$. The observation that small angular limestone fragments were observed in MH98 (Kern et al., 2011) which yielded the largest amount of carbon in Step2 fraction and presented the oldest apparent age (Table 1) supports this potential explanation.

Four out of the 11 analyzed samples produced detectable tritium activity (Table 2, Figure 2) despite the fact that in a previous pilot study none of eight test samples provided detectable tritium activity using the less sensitive liquid scintillation counting (LSC) technique (Kern et al. 2011). A technical explanation could be that the detection limit at the LSC method was ten times higher because it was not possible to apply electrolytic enrichment due to the small size of the sample. The ice core derived tritium record was compared to the regionally available historical inventories (Figure 2).

The peak (37.2 $\pm 1.2 \mathrm{TU})$ argues that the cave ice layer from the -0.76 to -0.86 depth range enclosed the atmospheric precipitation which fell in the mid-1960s period. Keeping in mind that the Saarhalle ice body has shown a continuously negative mass balance at least since 1996 (average surface ice loss rate: $7 \mathrm{~cm} \mathrm{yr}^{-1}$; Mais and Pavuza 2000) and documented until 2014. This fact not only excludes the existence of recent ice at the surface but also corresponds with $91 \mathrm{~cm}$ of cumulative ice loss before 2009 . Hence $0.91 \mathrm{~m}$ can be added to the depth measured beneath the Sept 2009 ice surface to obtain a corrected depth scale for 1996. Consequently, the ${ }^{3} \mathrm{H}$-peak might be within the depth range represented by the MH14 or MH15 samples and the estimated ice accumulation for the pre-1996 period is in fact 5.06-5.2 $\mathrm{cm} / \mathrm{yr}$. Using this average ice accumulation rate, the age of the ice layer sampled at the top of the ice block in 2009 was estimated to 1978 AD. 

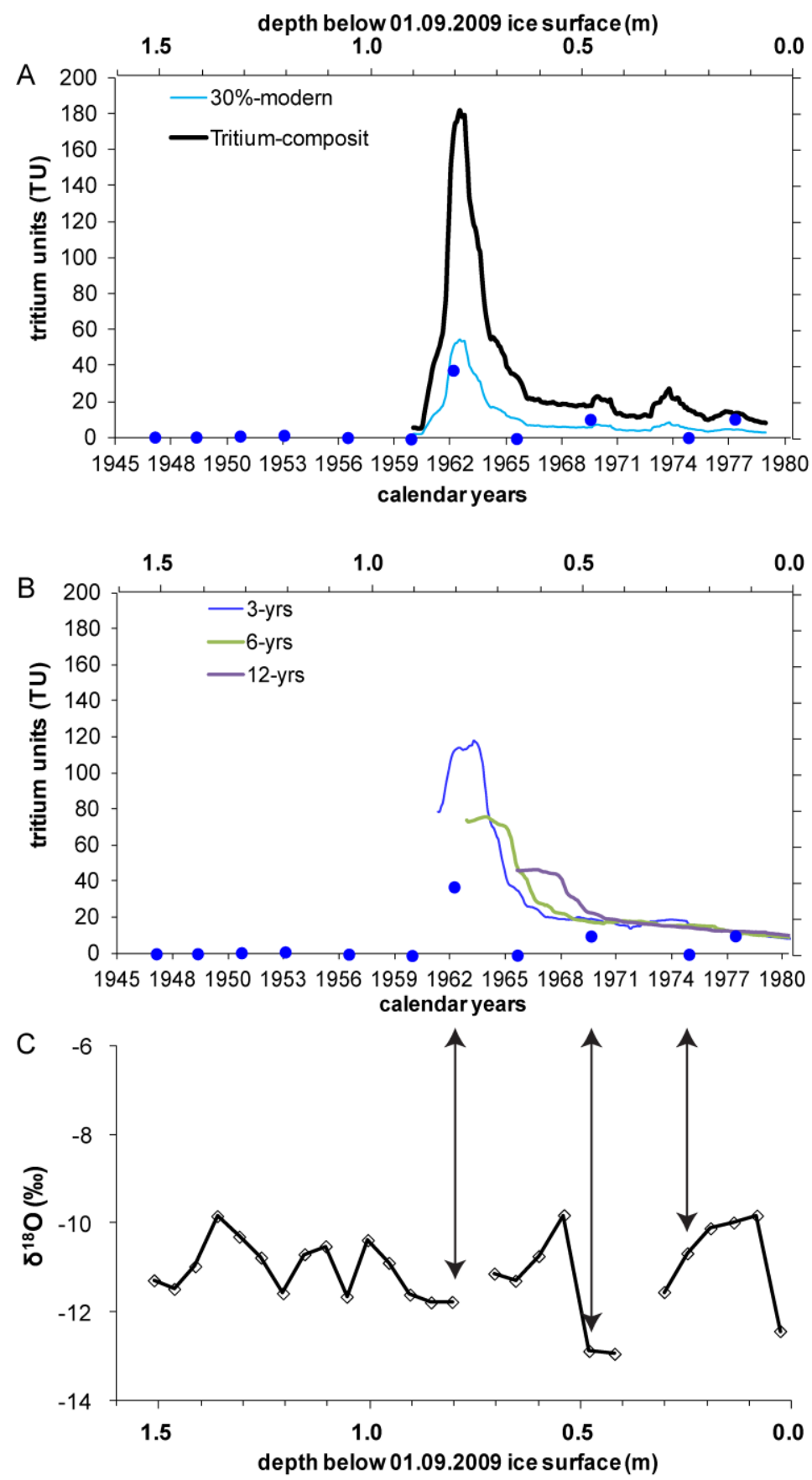

Figure 2 Tritium activity in regional precipitation (composite of monthly data from Feuerkogel and Vienna and decay corrected to 01.09.2009) and Saarhalle ice core obtained using the ${ }^{3} \mathrm{He}$-ingrowth method (blue dots). A: Decay corrected annual mean ${ }^{3} \mathrm{H}$ activities of precipitation (black) and the dampened signal assuming constant mixing of $30 \%$ modern precipitation and $70 \%$ tritium-free old water. B: Decay corrected monthly ${ }^{3} \mathrm{H}$ activities of precipitation smoothed with 3-yr (blue), 6-yr (green), and 12-yr (purple) moving averages simulating multiannual mixing in the karstic reservoir during the infiltration process. $\mathrm{C}$ : Stable oxygen isotope composition of the cave ice samples in the upper $1.5 \mathrm{~m}$ section of the Saarhalle ice core (Kern et al., 2011). 
Preprint of Kern Z., Molnár, M., Palcsu, L. Pavuza R. (2018) Age estimates on the deposition of the cave ice block in the Saarhalle Dachstein-Mammoth Cave (Mammuthöhle, Austria) based on ${ }^{3} \mathrm{H}$ and ${ }^{14} \mathrm{C}$. RAdiocarbon 60: 1379-1389. DOI:10.1017/RDC.2018.96

However, the magnitude of the ${ }^{3} \mathrm{H}$-peak is obviously far below the decay-corrected activity of the precipitation of the mid-1960s (Figure 2a). Two simple hypotheses were tested as potential explanations of the dampened signal found in the cave ice. The first one simulated the effect of constant and uniform dilution with a tritium-free water source (e.g. old karst water). The result obtained was that a mixture of $\sim 30 \%$ modern precipitation and $70 \%$ old infiltrated water might produce activity comparable to that of mid-1960s infiltration as observed in the ice core (Figure 2a). In this case, however, the simulated infiltration from the later precipitation should be dampened to a level of $\sim 1 \mathrm{TU}$, while in contrast, relatively high ( $>10 \mathrm{TU}$ ) activity levels have also been found at depths of $0.14 \mathrm{~m}$ and $0.48 \mathrm{~m}$. In testing the second hypothesis, multiannual mixing in the karstic reservoir during the infiltration process was simulated, simply smoothing decay-corrected regional monthly precipitation ${ }^{3} \mathrm{H}$. The results showed that $\sim 12 \mathrm{yr}$ mixing could bring the peak down to the level measured in the ice core (Figure $2 \mathrm{~b}$ ). However, the ${ }^{3} \mathrm{H}$ activity of the water supplied from such a well-mixed reservoir would be continuously at the $>10$ TU level after the mid-1960s. So, in this case we are again faced with a contradiction, seeing the $\sim 0 \mathrm{TU}$ samples measured at depths of 0.25 and $0.65 \mathrm{~m}$.

The pattern suggests that an "old" tritium-free component may be mixed with the "modern" meteoric component, resulting in the observed intermediate levels of ${ }^{3} \mathrm{H}$. This mixed water sources scheme conforms to the earlier explanation offered for the stable isotope characteristics of the Saarhalle ice core (Kern et al. 2011). Since the amount weighted $\delta^{18} \mathrm{O}$ value of the surface precipitation $(-12.79 \%$ o $)$ especially the winter season precipitation $(-14.05 \%$ ) (Kern et al., 2011), which is the main contribution to infiltration, is significantly more depleted compared to the average $\delta^{18} \mathrm{O}$ value of three local karst springs $(-12.16 \%$ o Scheidleder et al., 2001) a correspondence between the tritium-free points (MH05 and MH12) to less depleted stable isotope compositions compared to $\delta^{18} \mathrm{O}$ values of the samples (MH03, MH09 and MH15) with elevated ${ }^{3} \mathrm{H}$ activity might further support this theory. However, the correspondence, unfortunately, is not fully conclusive. Stable oxygen isotope compositions of MH05 and MH12 are less depleted compared to MH15 or MH09, however MH03 does not show similarly negative value (Figure $2 \mathrm{c}$ ).

Finally we note that smaller ice deposits could be abundant in similar high Alpine karstic system approaching the vicinity of, or even penetrating into the periglacial zone. These smaller ice patches probably might also act as temporary reservoir for formerly infiltrated meteoric waters. Refreezing of meltwater released from this kind of ice patches or frozen conduits might further complicate the genesis of larger ice deposits in similar Alpine system. Extrapolating the estimated late- $20^{\text {th }}$ century ice accumulation rate $(5.06-5.2 \mathrm{~cm} / \mathrm{yr})$ to the depths of MH21 and MH24 gave dates of 1957 and $~ 1953$, respectively, indicating a remarkable discrepancy between the age of the particulate organic matter (Table 1) and its host water/ice. The reliability of these extrapolated dates at the onset of the era of anthropogenic tritium contamination are supported by the fact that consistent ${ }^{3} \mathrm{H}$ activity measured in the deeper samples are in close agreement with the expected decayed value ( $\sim 0.2 \mathrm{TU}$ ) from the $\sim 5 \mathrm{TU}$ natural ${ }^{3} \mathrm{H}$ of precipitation in Central Europe (Roether 1967).

The obvious contrast between the deposition date estimated by the accumulation rate and obtained from the ${ }^{14} \mathrm{C}$ analysis of the water-insoluble organic carbon can be explained by the fact that water frozen into the ice layer might have already been carrying an aged organic carbon (e.g. aged soil carbon) during infiltration. This is quite plausible, since soil organic matter with a radiocarbon age exceeding 2,000 years has frequently been reported in Central Europe (Molnár et al. 2004), and the radiocarbon age of organic matter in subsoils $(>1 \mathrm{~m}$ depth) in all studied soil types worldwide exceeded 1,000 years (Rumpel and Kögel-Knabner 
Preprint of Kern Z., Molnár, M., Palcsu, L. Pavuza R. (2018) Age estimates on the deposition of the cave ice block in the Saarhalle Dachstein-Mammoth Cave (Mammuthöhle, Austria) based on ${ }^{3} \mathrm{H}$ and ${ }^{14} \mathrm{C}$. Radiocarbon 60: 1379-1389. DOI:10.1017/RDC.2018.96

2011). In extreme cases, mean ${ }^{14} \mathrm{C}$ ages of $>6800 \mathrm{yr}$ have been reported for certain organic fractions of soils in the subalpine range of the Italian Alps (Egli et al. 2009).

The reservoir age bias $(\Delta \mathrm{R})$ of the $400^{\circ} \mathrm{C}$ fractions for $\mathrm{MH} 21$ and $\mathrm{MH} 24$ were estimated and rounded to the nearest integer as

$\Delta \mathrm{R}_{\mathrm{MH} 21}=\mathrm{CRA}_{\mathrm{MH} 21}-\mathrm{exCRA}_{\mathrm{MH} 21}=1180-(-269.2)=1449$

and

$\Delta \mathrm{R}_{\mathrm{MH} 24}=\mathrm{CRA}_{\mathrm{MH} 24}-\mathrm{exCRA}_{\mathrm{MH} 24}=1790-(201.8)=1588$

where CRA stands for 'conventional radiocarbon age' of the sample (Table 1) and exCRA is the expected conventional age corresponding to the ${ }^{3} \mathrm{H}$ based extrapolated ages of $\mathrm{MH} 21$ and MH24 drawn from the pentennial mean values of the calibration curve of the NH1 zone for Modern Time (Bomb13NH1.14c available in OxCal 4.2.4; Bronk Ramsey 2013).

For the mean reservoir bias $1519 \pm 70 \mathrm{BP}$ can be calculated from the individual estimates presented above. Assuming a constant average reservoir bias for the entire dated history of the cave ice, the raw ${ }^{14} \mathrm{C}$ ages of the $400^{\circ} \mathrm{C}$ fractions of the deeper samples were corrected using the estimated mean $\Delta \mathrm{R}$ (Table 1). The uncertainty of the bias corrected conventional dates was estimated from the analytical uncertainty and the uncertainty of the estimated mean $\Delta R$ following a Gaussian error propagation. The most likely age range of the calibrated age distribution of the deepest analyzed sample (MH98) is 2060-1608 cal BC accounting for $91.7 \%$ probability. Linear extrapolation to the bottom ice layer $(5.28 \mathrm{~m})$ based on the depths and median calibrated dates obtained for MH92 and MH98 gave 2590 cal BC.

The recent comprehensive compilation of ${ }^{14} \mathrm{C}$ dates of organic remains in East Alpine ice caves (Spötl et al. 2018) presented three data from the Feenpalast deposit. A wood remain found at the base at the retreating cliff in the highest part of the Feenpalast, the second largest ice block in the Dachstein-Mammoth Cave, gave a conventional age of $695 \pm 35$ BP (Mais and Pavuza 2000) while two wood samples collected at deeper layers are slightly older ( $851 \pm 45 \mathrm{BP}$ and $1133 \pm 40 \mathrm{BP}$, Plan and Pavuza unpubl). The new radiometric ages argue for a much older cave ice deposit of the Saarhalle chamber compared to the Feenpalast chamber of the Dachstein-Mammoth Cave.

The earliest date presented in the wood record from the Hundsalm Ice Cave - providing the largest currently available radiocarbon dataset $(\mathrm{n}=19)$ for an Alpine ice cave - was $2664 \pm 32$ BP (895-796 cal BC) while the estimated age of four other samples was also $\sim 1400$ years (Spötl et al. 2014). Spötl et al. (2018) compiled the radiocarbon dates on other vegetal remains recovered occasionally from cave ice deposits in the Austrian Alps and recalibrated them using the current calibration dataset. Two wood samples from the basal ice of Eisgruben Eishöhle (Sarstein, Upper Austria) yielded $2210 \pm 70$ BP (400-65 cal BC) and $4520 \pm 50$ BP (3366-3030 cal BC), respectively (Achleitner 1995; R Pavuza 2012, unpublished). A tree trunk released by the melting ice in Schneeloch, an ice-hosting shaft in the Schneealpe (Styria), was dated to $4360 \pm 30$ BP (3085-2904 cal BC; Herrmann et al. 2010). A single date was presented for Kraterschacht (Sengsengebirge) with $886 \pm 45$ BP (1032-1242 cal AD; Weißmair 2011).

In light of these data the Saarhalle ice block is among the oldest ice deposits of the Alps. The preserved $\sim 4000$ year-long cave ice record definitely requires further research in the future.

\section{CONCLUSIONS}

The stepped combustion technique revealed a remarkable difference between the ${ }^{14} \mathrm{C}$ activity of insoluble carbon fractions of the studied cave ice samples from the Saarhalle DachsteinMammoth Cave combusted at $400^{\circ} \mathrm{C}$ and $800^{\circ} \mathrm{C}$. The age-relation obtained for the $800^{\circ} \mathrm{C}$ fractions contradicted the stratigraphic position of the samples; while the ages obtained for the 
Preprint of Kern Z., Molnár, M., Palcsu, L. Pavuza R. (2018) Age estimates on the deposition of the cave ice block in the Saarhalle Dachstein-Mammoth Cave (Mammuthöhle, Austria) based on ${ }^{3} \mathrm{H}$ and ${ }^{14} \mathrm{C}$. Radiocarbon 60: 1379-1389. DOI:10.1017/RDC.2018.96

$400^{\circ} \mathrm{C}$ fractions conformed to the stratigraphy. However, the $400{ }^{\circ} \mathrm{C}$ conventional ${ }^{14} \mathrm{C}$ age results still provided only maximum age estimates (the ice layer cannot be older than this age) because the water frozen the ice layer might have already carried aged organic carbon (e.g. transported from the aged soil carbon at the surface during infiltration). Tritium activities analyzed using the ${ }^{3} \mathrm{He}$-ingrowth method clearly indicated the contribution of modern water at least down to a depth of $1.21 \mathrm{~m}$. Comparing the ${ }^{3} \mathrm{H}$ based extrapolated ages of samples at $1.11 \mathrm{~m}(\mathrm{MH} 21)$ and $1.26 \mathrm{~m}(\mathrm{MH} 24)$ to the expected atmospheric signal of the calibration curve of $\mathrm{NH} 1$ zone, an average ${ }^{14} \mathrm{C}$ reservoir age bias of $\sim 1500 \mathrm{BP}$ was obtained. Assuming that the reservoir bias in the ${ }^{14} \mathrm{C}$ signal was continuous and constant over the deposition history of the Saarhalle ice block, the corrected deposition date for the deepest analyzed sample could be estimated to $\sim 1830$ cal BC (2134-2081 (2.9\%) 2060-1608 (91.7\%) 1581$1562(0.8 \%))$ while a linear extrapolation based on the depths and median calibrated dates obtained for MH92 and MH98 to the bottom ice layer gave 2590 cal BC.

\section{ACKNOWLEDGEMENTS}

The research was supported by the European Union and the State of Hungary, co-financed by the European Regional Development Fund in the project of GINOP-2.3.2.-15-2016-00009 'ICER' and LP2012-27/2012. The authors acknowledge Dachsteinhöhlen Cave Management (Stephan Höll) for permission to study the cave ice. This is contribution No.62 of $2 \mathrm{ka}$ Palæoclimatology Research Group.

\section{REFERENCES}

Achleitner A. 1995. Zum Alter des Höleneises in der Eisgruben-Eishöhle im Sarstein (Oberösterreich). Die Höhle, 46(1):1-5.

Behm M, Hausmann H. 2008. Determination of ice thickness in Alpine caves using georadar. In: Kadebskaya, O.; Mavlyudov, B.R.; Pyatunin, M. (eds) 3rd International Workshop on Ice Caves Proceedings, Kungur, Russia, p. 53-8.

Borsato A, Miorandi R, Flora O. 2006. I depositi di ghiaccio ipogei della Grotta dello Specchio e del Castelletto di Mezzo (Dolomiti di Brenta, Trentino): morfologia, età ed evoluzione recente. Studi Trent. Sci. Nat., Acta Geol 81:53-74.

Bronk Ramsey C. 2009. Bayesian analysis of radiocarbon dates. Radiocarbon 51(1):337-60. Bronk Ramsey C 2013. OxCal project, Version 4.2.4. Retrieved April 2016 https://c14.arch.ox.ac.uk/oxcal/OxCal.htmlColucci RR, Forte E, Maggi V, Stenni B, Barbante C, Bertò M, Dreossi G, Filipazzi M, Gabrieli J, Hoffmann H, Lenaz D. 2016. The Vasto Ice Cave in the South-eastern Alps, Europe: preliminary results from an ice core analysis. In: Mihevc A, Hajna Zupan N, Gostincar P (eds.) 7th International Workshop on Ice Caves: Program Guide and Abstracts, Postojna: Karst Research Institute ZRC SAZU pp.42-3.

Colucci RR, Luetscher M, Festi D, Mosley GE, Schwikowski M, Edwards RL. 2018. On issues related to dating techniques in ice caves. In: Serrano E. (ed) 8th International Workshop on Ice Caves: Scientific program and Abstracts, GIR PANGEA, pp.23.

Egli M, Sartori G, Mirabella A, Favilli F, Giaccai D, Delbos E. 2009. Effect of north and south exposure on organic matter in high Alpine soils. Geoderma 149(1):124-36.

Gradziński M, Hercman H, Peresviet-Soltan A, Zelinka J, Jelonek M. 2016. Radiocarbon dating of fossil bats from Dobšina Ice Cave (Slovakia) and potential palaeoclimatic implications. Annales Societatis Geologorum Poloniae 86:341-50. doi:10.14241/asgp.2016.016

Hausmann H, Behm M. 2011. Imaging the structure of cave ice by ground-penetrating radar, The Cryosphere 5:329-40, doi:10.5194/tc-5-329-2011 
Preprint of Kern Z., Molnár, M., Palcsu, L. Pavuza R. (2018) Age estimates on the deposition of the cave ice block in the Saarhalle Dachstein-Mammoth Cave (Mammuthöhle, Austria) based on ${ }^{3} \mathrm{H}$ and ${ }^{14} \mathrm{C}$. RAdiocarbon 60: 1379-1389. DOI:10.1017/RDC.2018.96

Hoffmann H, Bohleber P, Wagenbach, D. 2015. Micro radiocarbon dating-applications and challenges in Alpine glaciology. Geophysical Research Abstracts 17:EGU2015-9119,

Hercman H, Gąsiorowski M, Gradziński M, Kicińska D. 2010. The first dating of cave ice from the Tatra Mountains, Poland and its implication to palaeoclimate reconstructions. Geochronometria 36:31-8.

Herrmann E, Pucher E, Nicolussi K. 2010. Das Schneeloch auf der Hinteralm (Schneealpe, Steiermark): Speläomorphologie, Eisveränderung, Paläozoologie und Dendrochronologie. Die Höhle 61:57-72.

Hoffmann H, Bohleber P, Wagenbach D. 2015. Micro radiocarbon dating-applications and challenges in Alpine glaciology. Geophysical Research Abstracts 17, EGU2015-9119

Hoffmann H, Preunkert S, Legrand M, Leinfelder D, Bohleber P, Friedrich R, Wagenbach D. 2017. A new sample preparation system for micro-14C dating of glacier ice with a first application to a high Alpine ice core from Colle Gnifetti (Switzerland). Radiocarbon (in press) DOI:10.1017/RDC.2017.99

IAEA 2010. Global Network of Isotopes in Precipitation, The GNIP Database 2010, URL: <http://www.isohis.iaea.org > . (last access: 9 July 2012)

Jenk TM, Szidat S, Schwikowski M, Gäggeler HW, Brütsch S, Wacker L, Synal HA, Saurer M. 2006. Radiocarbon analysis in an Alpine ice core: record of anthropogenic and biogenic contributions to carbonaceous aerosols in the past (1650-1940). Atmos. Chem. Phys. 6:538190, doi:10.5194/acp-6-5381-2006

Jenk TM, Szidat S, Schwikowski M, Gäggeler HW, Wacker L, Synal HA, Saurer M. 2007. Microgram level radiocarbon $\left({ }^{14} \mathrm{C}\right)$ determination on carbonaceous particles in ice. $\mathrm{Nucl}$. Instrum. Meth. Phys. Res. B 259:518-25, doi:10.1016/j.nimb.2007.01.196,

Kern, Z. 2018 Dating cave ice deposits. In: Persoiu, A. and Lauritzen, SE (eds) Ice Caves, Elsevier, pp.109-22.

Kern Z, Molnár M, Svingor É, Perşoiu A, Nagy B. 2009. High resolution well preserved tritium record in the ice of Borţig Ice Cave, Bihor Mountains, Romania. The Holocene 19:729-36, doi:10.1177/0959683609105296

Kern Z., Fórizs I, Pavuza R, Molnár M, Nagy B. 2011. Isotope hydrological studies of the perennial ice deposit of Saarhalle, Mammuthöhle, Dachstein Mts, Austria. The Cryosphere 5:291-8, doi:10.5194/tc-5-291-2011

Kralik M., Papesch W. Stichler,W. 2003 Austrian Network of Isotopes in Precipitation (ANIP): Quality assurance and climatological phenomenon in one of the oldest and densest networks in the world. Isot. Hydrol. Integr. Water Resour. Manag. 23:146-9.

Lucas LL., Unterweger MP. 2000. Comprehensive review and critical evaluation of the halflife of tritium. J. Res. Natl. Inst. Stand. Technol 105:541-49.

Luetscher M, Bolius D, Schwikowski M, Schotterer U, Smart PL. 2007. Comparison of techniques for dating of subsurface ice from Monlesi ice cave, Switzerland, J Glaciol 53:37484 .

Luetscher, M. 2013. Glacial processes in caves. In: Frumkin, A. (ed), Treatise on Geomorphology. Academic Press, San Diego, CA, vol.6, Karst Geomorphology, p.258-66.

Mais K, Pavuza R. 2000. Hinweise zu Höhlenklima und Höhleis in der Dachstein Mammuthöhle (Oberösterreich). Die Höhle 51:121-5.

May B, Spötl C, Wagenbach D, Dublyansky Y, Liebl J. 2011. First investigations of an ice core from Eisriesenwelt cave (Austria), The Cryosphere 5:81-93, doi:10.5194/tc-5-81-2011

Molnár M, Joó K, Barczi A, Szántó Z, Futó I, Palcsu L, Rinyu L. 2004. Dating of total soil organic matter used in kurgan studies. Radiocarbon 46(1):413-9 
Preprint of Kern Z., Molnár, M., Palcsu, L. Pavuza R. (2018) Age estimates on the deposition of the cave ice block in the Saarhalle Dachstein-Mammoth Cave (Mammuthöhle, Austria) based on ${ }^{3} \mathrm{H}$ and ${ }^{14} \mathrm{C}$. Radiocarbon 60: 1379-1389. DOI:10.1017/RDC.2018.96

Molnár M, Janovics R, Major I, Orsovszki J, Gönczi R, Veres M, Leonard AG, Castle SM, Lange TE, Wacker L, Hajdas I, Jull AJT, 2013a. Status report of the new AMS C-14 sample preparation lab of the Hertelendi Laboratory of Environmental Studies, Debrecen, Hungary. Radiocarbon 55:665-76

Molnár M, Rinyu L, Veres M, Seiler M, Wacker L, Synal HA, 2013b. EnvironMICADAS: a mini 14C-AMS with enhanced gas ion source interface in the Hertelendi Laboratory of Environmental Studies (HEKAL), Hungary. Radiocarbon 55:338-44. doi: 10.2458/azu_js_rc.55.16331.

Munroe JS, O'Keefe SS, Gorin AL. 2018. Chronology, stable isotopes, and glaciochemistry of perennial ice in Strickler Cavern, Idaho, USA. GSA Bulletin 130:175-192, https://doi.org/10.1130/B31776.1

Palcsu L, Major Z, Köllő Z, Papp L. 2010. Using an ultrapure ${ }^{4} \mathrm{He}$ spike in tritium measurements of environmental water samples by the ${ }^{3} \mathrm{He}$-ingrowth method. Rapid Commun Mass Spectrom 24:698-704, DOI: 10.1002/rcm.4431

Perşoiu A, Onac BP, Wynn JG, Blaauw M, Ionita M, Hansson M. 2017. Holocene winter climate variability in Central and Eastern Europe. Scientific Reports 7(1):1196

Perşoiu A, Pazdur A. 2011. Ice genesis and its long-term mass balance and dynamics in Scărişoara Ice Cave, Romania. The Cryosphere 5:45-53. doi:10.5194/tc-5-45-2011

Reimer PJ, Bard E, Bayliss A, Beck JW, Blackwell PG, Bronk Ramsey C, Grootes PM, Guilderson TP, Haflidason H, Hajdas I, Hatte C, Heaton TJ, Hoffmann DL, Hogg AG, Hughen KA, Kaiser KF, Kromer B, Manning SW, Niu M, Reimer RW, Richards DA, Scott EM, Southon JR, Staff RA, Turney CSM, van der Plicht J, 2013. IntCal13 and Marine13 radiocarbon age calibration curves 0-50,000 years cal BP. Radiocarbon 55(4):1869-87.

Rinyu L, Orsovszki G, Futó I, Veres M, Molnár M. 2015. Application of zinc sealed tube graphitization on sub-milligram samples using EnvironMICADAS. Nucl. Instrum. Meth. Phys. Res. B, 361:406-13.

Roether W. 1967. Estimating the tritium input to groundwater from wine samples: groundwater and direct run-off contribution to central European surface waters. Proceedings of IAEA Conference on Isotopes in Hydrology, IAEA, Vienna, p.73-90.

Rumpel C, Kögel-Knabner I. 2011. Deep soil organic matter-a key but poorly understood component of terrestrial C cycle. Plant Soil 338:143-58. https://doi.org/10.1007/s11104-010$\underline{0391-5}$

Sancho C, Belmonte A, López-Martínez J, Moreno A, Bartolomé M, Calle M, Santolaria P. 2012. Potencial paleoclimático de la cueva helada A294 (Macizo de Cotiella, Pirineos, Huesca). Geogaceta 52:101-4.

Sancho C, Belmonte Á, Bartolomé M, Moreno A, Leunda M, López-Martínez J. 2018. Middle-to-late Holocene palaeoenvironmental reconstruction from the A294 ice-cave record (Central Pyrenees, northern Spain). Earth and Planetary Science Letters 484:135-44.

Scheidleder A, Boroviczeny F, Graf W, Hofmann T, Mandl G, Schubert G, Stichler W, Trimborn P, Kralik M. 2001. Pilotprojekt "Karstwasser Dachstein": vol. 2 Karsthydrologie und Kontaminationsrisiko von Quellen, Umweltbundesamt Monographie 108:1-155, Wien, Umweltbundesamt

Spötl C, Reimer PJ, Luetscher M. 2014. Long-term mass balance of perennial firn and ice in an Alpine cave (Austria): Constraints from radiocarbon-dated wood fragments. The Holocene 24:165-75. doi: 10.1177/0959683613515729

Spötl C, Plan L, Christian E. 2016. Höhlen und Karst in Österreich. - 752 p., Linz Spötl C, Wimmer M, Pavuza R, Plan L. 2018. Ice caves in Austria. In: Persoiu, A. and Lauritzen, SE (eds) Ice Caves, Elsevier, p.237-62. 
Preprint of Kern Z., Molnár, M., Palcsu, L. Pavuza R. (2018) Age estimates on the deposition of the cave ice block in the Saarhalle Dachstein-Mammoth Cave (Mammuthöhle, Austria) based on ${ }^{3} \mathrm{H}$ and ${ }^{14} \mathrm{C}$. Radiocarbon 60: 1379-1389. DOI:10.1017/RDC.2018.96

Stuiver M, Polach HA. 1977. Discussion: reporting of ${ }^{14}$ C data. Radiocarbon 19(2):355-63.

Uglietti C, Zapf A, Jenk TM, Sigl M, Szidat S, Salazar G, Schwikowski M. 2016. Radiocarbon dating of glacier ice: overview, optimisation, validation and potential. The Cryosphere 10:3091-105, doi:10.5194/tc-10-3091-2016

Újvári G, Molnár M, Páll-Gergely B. 2016. Charcoal and mollusc shell 14 C-dating of the Dunaszekcső loess record, Hungary. Quaternary Geochronology 35:43-53.

Weißmair R. 2011. Eisdatierung und Eisveränderungen im Kraterschacht (1651/24, Sengsengebirge, Oberösterreich) zwischen 1992 und 2009. Die Höhle 62:27-30. 